\title{
Effect of Water-Cement Ratio on the Macrocell Polarization Behavior of Reinforcing Steel
}

\author{
Zhonglu Cao, Makoto Hibino, and Hiroki Goda \\ Concrete laboratory, Department of Civil Engineering, Kyushu Institute of Technology, Kitakyushu-shi 804-8550, Japan \\ Correspondence should be addressed to Zhonglu Cao; caozhonglu@126.com
}

Received 11 August 2014; Accepted 19 October 2014; Published 16 November 2014

Academic Editor: Yongping Chen

Copyright (C) 2014 Zhonglu Cao et al. This is an open access article distributed under the Creative Commons Attribution License, which permits unrestricted use, distribution, and reproduction in any medium, provided the original work is properly cited.

\begin{abstract}
The effect of water-cement ratio on the macrocell polarization behavior of reinforcing steel embedded in cement mortars was investigated by comparing and analyzing the macrocell polarization ratios and slopes of anodic and cathodic steels. Based on the experimental results, the relationship between macrocell potential difference and macrocell current density was also analyzed, and the mechanism of macrocell polarization affected by water-cement ratio was proposed. The results indicated that the water-cement ratios had little impact on the macrocell polarization ratios of cathode and anode. The lower water-cement ratio could reduce the macrocell current by decreasing the macrocell potential difference and increasing the macrocell polarization resistance of the cathode and anode.
\end{abstract}

\section{Introduction}

The water-cement ratio (W/C ratio) is one of the important parameters affecting the long-term properties of reinforced concrete. For cement pastes hydrated to the same degree, as the water-cement ratio decreases, the permeability of reinforced concrete decreases as well. The permeability of reinforced concrete is a critical factor limiting the penetration of chloride and the diffusion of carbon dioxide, oxygen, and other aggressive agents and therefore plays an important role in controlling the microcell and macrocell corrosion behaviors of reinforcing steel.

According to the study of Arya and Vassie [1], for the same area ratio of cathode to anode, a lower water-cement ratio, and hence lower permeability, could decrease the macrocell current flowing between cathodic steel and anodic steel. This lower current obtained from the lower permeability mix could probably be explained by the higher resistance of concrete and the lower transport rate of oxygen and ferrous ions, producing restrictions to the cathode and anode reaction kinetics. Similar results could be confirmed by the study of Vedalakshmi et al. [2], Hansson et al. [3], and Ohno et al. [4-7]. The results of Raupach [8] indicated that a reduction of the water-cement ratio from 0.6 to 0.5 yielded a further reduction in steel mass loss in the crack zone. This influence was especially pronounced after 24 weeks and then became much smaller after one year, which might be explained by the fact that the period up to depassivation was prolonged by a reduction of the water-cement ratio. However, after the onset of corrosion, the water-cement ratio had only a negligible influence.

All these studies as mentioned above only investigated the effect of water-cement ratio on the magnitude of macrocell current and did not investigate the possible influence of water-cement ratio on the macrocell polarization ratio of cathode and anode. When macrocell corrosion was observed, the cathode was cathodically polarized to a lower potential while the anode was anodically polarized to a higher potential. Whether the polarization ratios of the cathode and anode were controlled by water-cement ratio attracts the interests of the authors, and up to now, no literature gives the answer. Another consideration was that although these studies confirmed the positive role of a lower water-cement ratio in reducing the macrocell current flowing between the cathode and anode, they did not present the potential difference between the cathode and anode which also could be affected by the water-cement ratio. The relationship between macrocell current density and potential difference of steels in 


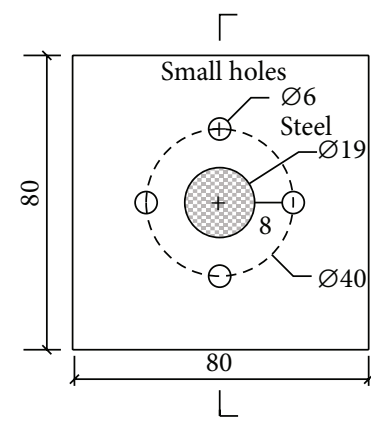

(a)

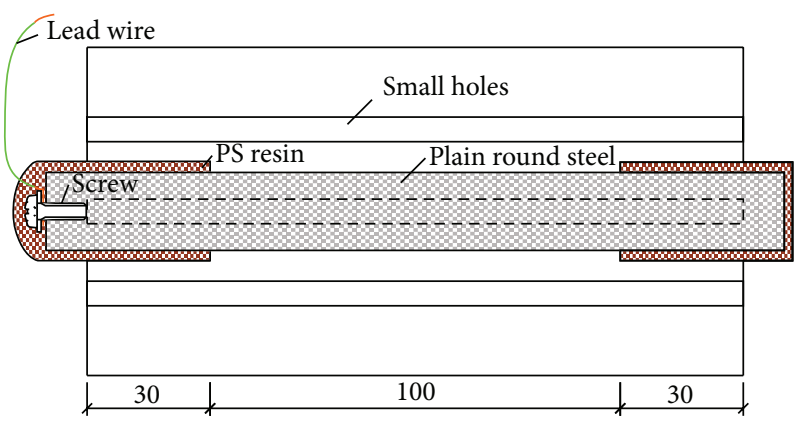

(b)

FIGURE 1: Schematic illustration of specimens used in this study (unit: $\mathrm{mm}$ ).

concrete with various water-cement ratios has yet to be elucidated.

In this study, the influence of water-cement ratio on the relationship between macrocell potential difference and macrocell current density will be analyzed. Subsequently, the influence of water-cement ratios on the macrocell polarization ratios and macrocell polarization slopes of the cathode and anode will be investigated, and then the mechanism of macrocell corrosion affected by water-cement ratios will be explained.

\section{Experimental}

2.1. Materials. Plain round mild steel bars $19 \mathrm{~mm}$ in diameter and $180 \mathrm{~mm}$ in length were used in the experiment. The chemical composition of the steel was (wt\%) $0.146 \mathrm{C} \%$, $0.223 \mathrm{Si} \%, 0.521 \mathrm{Mn} \%, 0.019 \mathrm{P} \%, 0.010 \mathrm{~S} \%$, and balanced Fe. At one end of the steel bar, a lead wire was fixed to the steel by screw and the connection area was sealed by PS resin. In order to prevent any atmospheric corrosion and enhance the reliability and accuracy of measurement, the two bare ends with $40 \mathrm{~mm}$ in length of the steel were firstly coated with PS resin and then were coated with epoxy resin. The exposed area of the steel was $59.7 \mathrm{~cm}^{2}$. The surface of the exposed area was polished by sandpaper number 180 and cleaned with acetone just prior to being placed in the mold so as to ensure the accuracy of the experimental results.

The corrosion behavior of steel bar was investigated in cement mortar block as shown in Figure 1. The mix proportion of mortar used in this study was presented in Table 1. Ordinary Portland cement that was utilized had a density of $3.15 \mathrm{~g} / \mathrm{cm}^{3}$ and met the specification requirements of JIS R5210. Sea sand passed through the JIS A 1102 sieve No.4 ( $4.75 \mathrm{~mm}$ opening) and washed by tap water was selected as the fine aggregate. Its density and water absorption were $2.58 \mathrm{~g} / \mathrm{cm}^{3}$ and $1.53 \%$, respectively. For some specimens, chloride ions ( $3 \mathrm{wt} \%$ of cement) were added into the cement mortar at the time of casting by means of $\mathrm{NaCl}$ dissolved in the mix water. It should be emphasized here that, in the real uncontaminated reinforced concrete structures, it takes time for steel to become passive. So, the steel was usually in passive state before the presence of chloride ions. The presence of chloride ions on the surface of steel was mainly
TABLE 1: Mix proportion of mortars used in this study.

\begin{tabular}{cccccc}
\hline $\begin{array}{c}\text { W/C } \\
\text { ratio }\end{array}$ & $\begin{array}{c}\text { Water } \\
\left(\mathrm{kg} / \mathrm{m}^{3}\right)\end{array}$ & $\begin{array}{c}\text { Cement } \\
\left(\mathrm{kg} / \mathrm{m}^{3}\right)\end{array}$ & $\begin{array}{c}\text { Sand } \\
\left(\mathrm{kg} / \mathrm{m}^{3}\right)\end{array}$ & $\begin{array}{c}\text { Air } \\
(\%)\end{array}$ & $\begin{array}{c}\text { Chloride } \\
(\text { wt \% of cement })\end{array}$ \\
\hline 0.70 & 228 & 325 & 1624 & $4 \%$ & $0 \%$ \\
0.70 & 228 & 325 & 1624 & $4 \%$ & $3 \%$ \\
0.60 & 277 & 462 & 1385 & $4 \%$ & $0 \%$ \\
0.60 & 277 & 462 & 1385 & $4 \%$ & $3 \%$ \\
0.45 & 224 & 497 & 1492 & $4 \%$ & $0 \%$ \\
0.45 & 224 & 497 & 1492 & $4 \%$ & $3 \%$ \\
\hline
\end{tabular}

attributed to the penetration of chloride ions from the external environment. When chloride ions were directly added into the cement mortar, there was no time for the steel to be passivated. Additionally, adding chloride ions into the cement mortar had an influence on the properties of mortar. The reasons for doing this in this study were, firstly, to accelerate the corrosion of steel and secondly to produce the same chloride content on the steel-concrete interface. All the specimens were allowed to set and harden in the mold for 1 day before being demolded and then cured for the next two weeks under water. After that, they were allowed to dry under a laboratory environment for another two weeks, prior to the beginning of experiment measurements.

2.2. Methods. Table 2 gives the cases that were investigated and analyzed in this study. Polished steels were used in both A-side and B-side in order to give the steels the same initial surface condition and reduce the impact of various steel surface conditions on the macrocell behaviors of the cathode and anode. The specimens in A-side and B-side had the same water-cement ratio but contained different chloride contents. The difference in chloride contents forms a greater potential difference between the steels in A-side and B-side and allows for clear observation of the macrocell polarization behaviors of the cathode and anode. The chloride content in the specimens of A-side was $0 \mathrm{wt} \%$ of cement while the chloride content in the specimens of B-side was $3 \mathrm{wt} \%$ of cement which was much higher than the chloride threshold level for active corrosion. 
TABLE 2: Case design for the effect of water-cement ratio.

\begin{tabular}{llcccc}
\hline Case number & A-side & B-side & Case number & A-side & B-side \\
\hline $9-1$ & P45-0-1 & P45-3-1 & $9-2$ & P45-0-2 & P45-3-2 \\
$10-1$ & P60-0-1 & P60-3-1 & $10-2$ & P60-0-3 & P60-3-2 \\
$11-1$ & P70-0-1 & P70-3-1 & $11-2$ & P70-0-2 & P70-3-2 \\
\hline
\end{tabular}

Note: in this table, the steel with polished surface was marked as P. The $\mathrm{W} / \mathrm{C}$ ratio of specimen was marked as 45,60 , and 70 . The chloride content of specimen was marked as 0 and 3 . The serial number of specimens was marked as 1, 2, and 3. For example of P45-0-1, P means the steel had polished surface, 45 means the $\mathrm{W} / \mathrm{C}$ ratio of specimen was $0.45,0$ means the chloride content of specimen was $0 \mathrm{wt} \%$ of cement, and 1 means the serial number of specimens was 1.

The experimental process is shown in Figure 2. The specimens in A-side and B-side were disconnected for two weeks and were then connected for another two weeks. These four weeks were defined as one cycle and 24 cycles were carried out in this study. A two-week duration was selected for both disconnected and connected periods, because it was a sufficient amount of time for the recovery and stabilization of steel corrosion state during the disconnected period and was also suitable for the stabilization of macrocell current and macrocell polarization during the connected period.

During the process of experiments, the half-cell potential $\left(E_{\text {corr }}\right)$ referred to the $\mathrm{Ag} / \mathrm{AgCl}$ electrode; the resistance of reinforcing steel (unit: $\Omega$ ) and resistance of mortar (unit: $\Omega$ ) were measured at set intervals using the CM-SE1, which is a device developed by Nippon Steel Techno Research for corrosion detection. Since the current imposed by the device was not uniformly distributed on the surface of steel and was greatly affected by the thickness of concrete cover and the diameter of reinforcing steel, the resistance of steel (unit: $\mathrm{k} \Omega \cdot \mathrm{cm}^{2}$ ) and resistance of mortar (unit: $\mathrm{k} \Omega \cdot \mathrm{cm}^{2}$ ) were a function of concrete cover thickness and steel diameter. In this study, they were calculated by the auxiliary software of this device, which fully considered the influence of concrete cover thickness and steel diameter. Before the measurement, water-saturated cotton was placed between the electrode of device and the surface of specimen to ensure good current transmission.

In order to distinguish the microcell corrosion current density and the macrocell corrosion current density and to better understand the relationship between them, the corrosion current density of steel in the disconnected periods was defined as the microcell corrosion current density of steel $[3,9-11]$. It was calculated by the use of the Stern-Geary equation: $i_{\mathrm{mi}}=B / R p$, where $R p$ was the resistance of steel and $B$ was a constant which was commonly considered to be $26 \mathrm{mV}$ for steel in corroded state and $52 \mathrm{mV}$ for steel in passive state.

In the connected periods of each cycle, the macrocell current flowing between A-side and B-side was measured by zero resistance ammeters (ZRA). The macrocell corrosion current density of steel was calculated by the equation: $i_{\mathrm{ma}}=I_{\mathrm{ma}} / A_{a}$, where $I_{\mathrm{ma}}$ was the macrocell current (unit: $\mu \mathrm{A}$ ) and $A_{a}$ (unit: $\mathrm{cm}^{2}$ ) was the surface area of steel that acted as an anode specimen. The anode specimen was defined as the specimen that produced electrons and could be judged from the direction

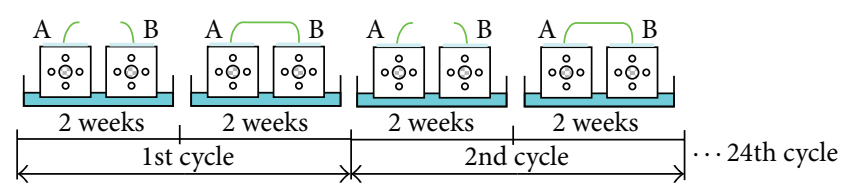

FigURE 2: Experimental process of this study.

of current flow. The direct measurement of macrocell current had been used effectively by some researchers. It had the advantage that the current measured was naturally flowing and did not result from the perturbation of the system. Its main disadvantage was that the current flowing within either of the two electrodes was not included and thus the measured macrocell current might be less than the true corrosion current. For some conditions, this effect could be significant, notably when the resistance of the concrete or mortar was too high to support the macrocell activity. For this reason, the specimens in A-side and B-side were partially immersed in water to enhance the electroconductivity of mortar.

\section{Results and Discussion}

3.1. Time Evolution Curves of Half-Cell Potential and Corrosion Current Density. The time evolution curves of half-cell potential $\left(E_{\text {corr }}\right)$, microcell current density, macrocell current density of steels, and the resistance of mortars for the cases designed in Table 2 were shown in Figure 3, Figure 4, and Figure 5, respectively. As indicated in these figures, in the disconnected periods, the half-cell potentials of steel in Aside were much higher than $-230 \mathrm{mV}$, and some of them were even higher than $-80 \mathrm{mV}$, while the half-cell potentials of steel in B-side were much lower than $-230 \mathrm{mV}$. Based on the ASTM C876 standard, corrosion probabilities of the steel in A-side were in the state of uncertainly or in the state of passivation with a possibility of $90 \%$ and the corrosion probabilities of steels in B-side were in the state of active corrosion with a possibility of $90 \%$. Seen from the microcell current density in the disconnected periods, the microcell current densities of steels in A-side were much lower than $0.1 \mu \mathrm{A} / \mathrm{cm}^{2}$ and about one order of magnitude lower than that of steels in B-side. So the steel in A-side acted as cathode while the steel in B-side acted as anode.

When the steel in A-side was connected with the steel in $\mathrm{B}$-side, due to the electrochemical driving force in terms of potential difference [12], the steel in A-side was cathodically polarized to a lower potential while the steel in B-side was anodically polarized to a higher potential. The electrons released by steel in B-side were transferred to and consumed by the steel in A-side, which led to the flow of current from the steel in A-side to the steel in B-side. The macrocell current not only accelerated the corrosion rate of the steel in B-side but also provided cathodic protection on the steel in A-side.

Seen from these figures, the time-variant characteristics of half-cell potential, microcell current density, macrocell current density of steels, and the resistance of mortars could be observed. With the increasing of time, the half-cell potential of steels exhibited a complex cyclical fluctuation, while 


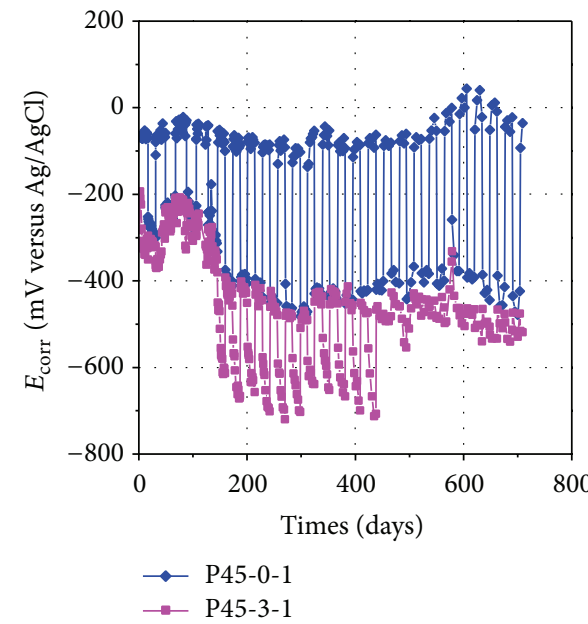

(a)

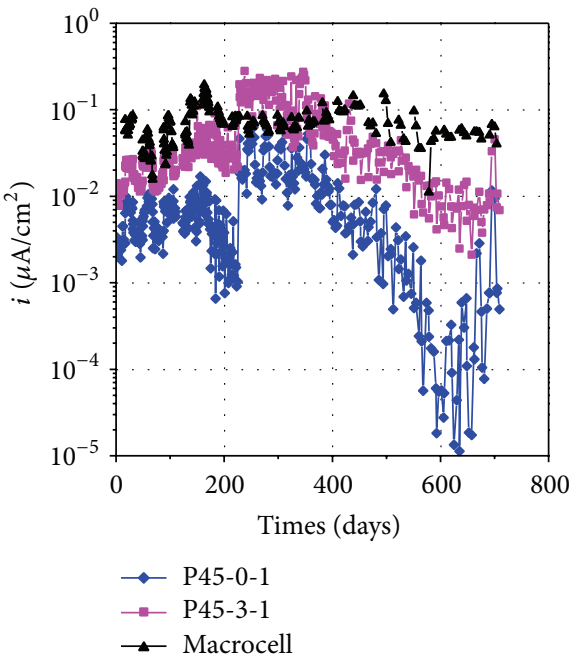

(c)

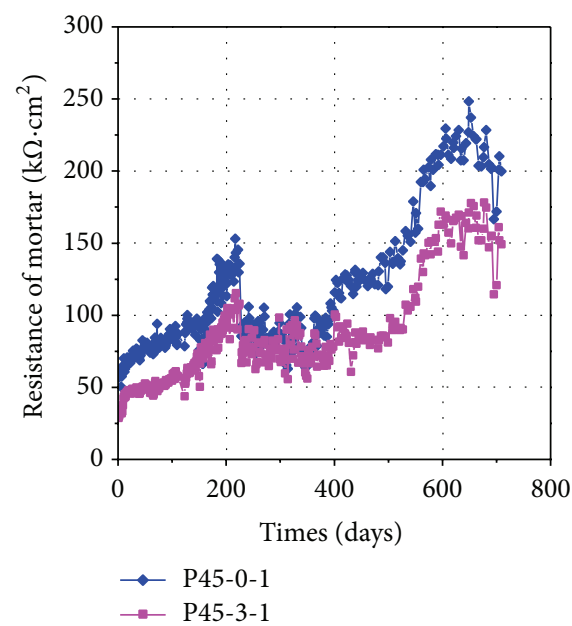

(e)

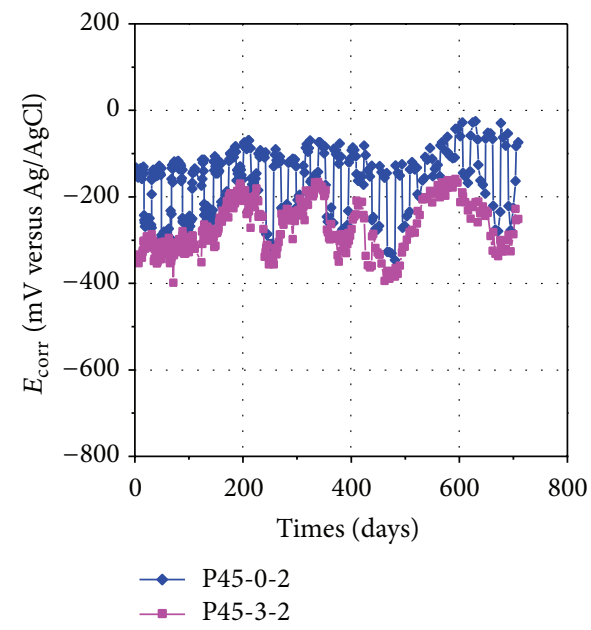

(b)

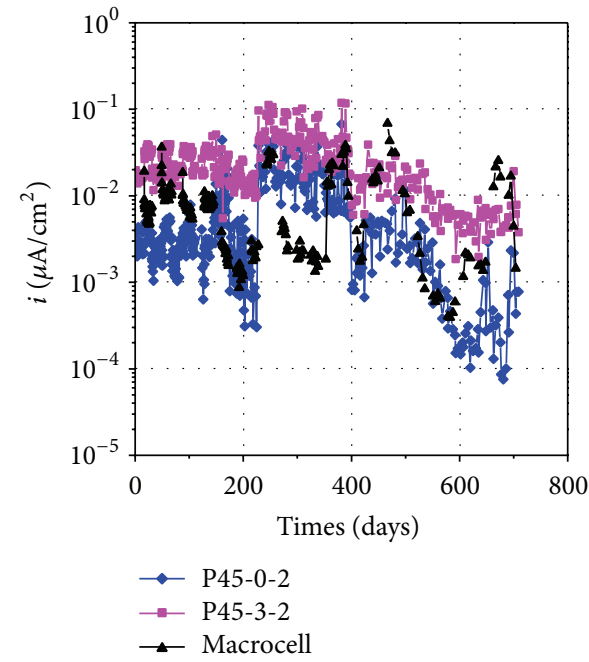

(d)

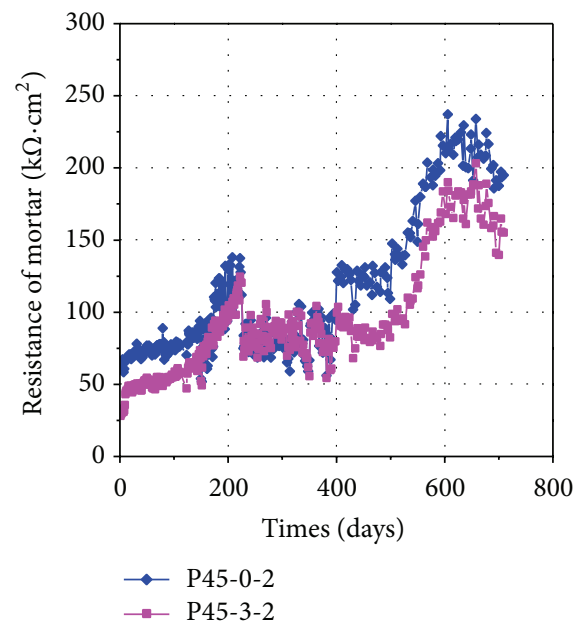

(f)

FIGURE 3: Time evolution curves of half-cell potential, microcell current density, macrocell current density, and resistance of mortars for cases with W/C ratio of 0.45. (a) Half-cell potential of steel in case 9-1, (b) half-cell potential of steel in case 9-2, (c) corrosion current density of steel in case 9-1, (d) corrosion current density of steel in case 9-2, (e) resistance of mortar in case 9-1, and (f) resistance of mortar in case 9-2. 


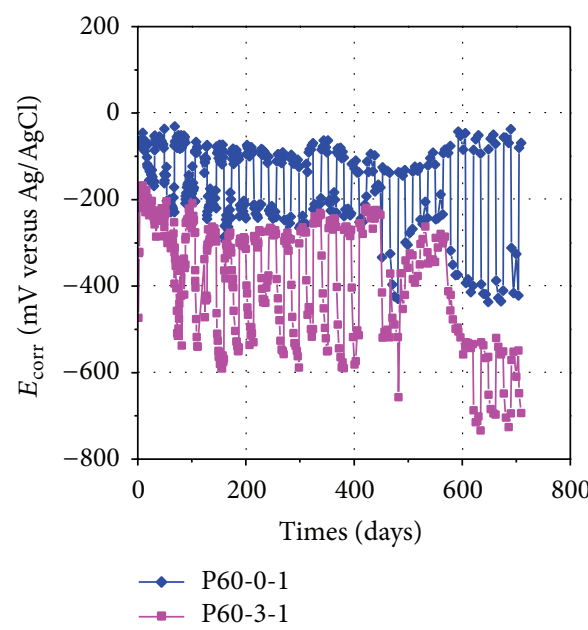

(a)

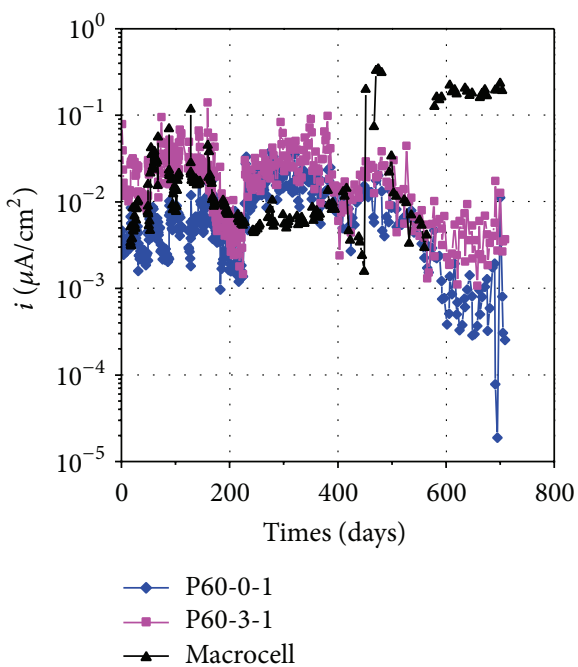

(c)

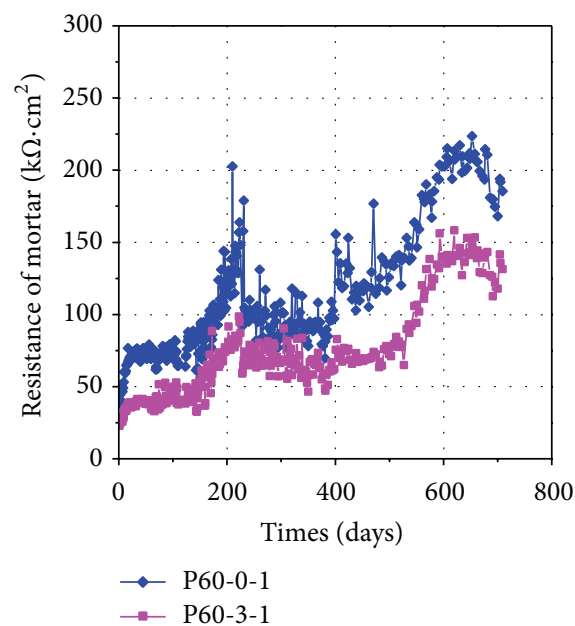

(e)

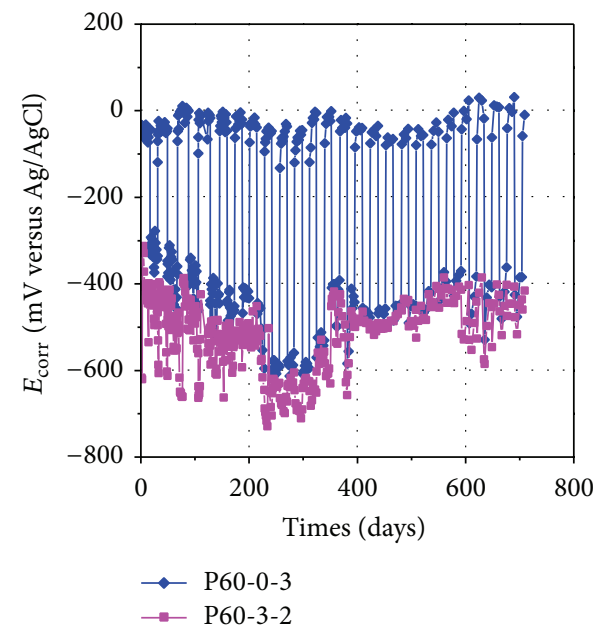

(b)

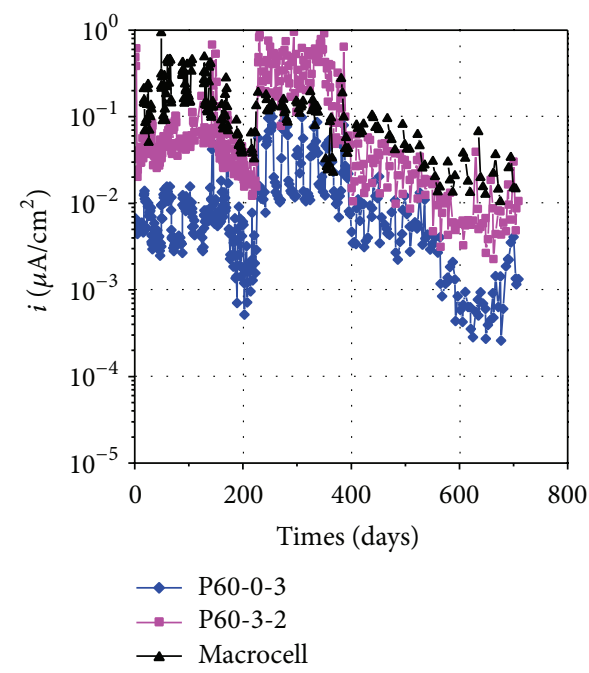

(d)

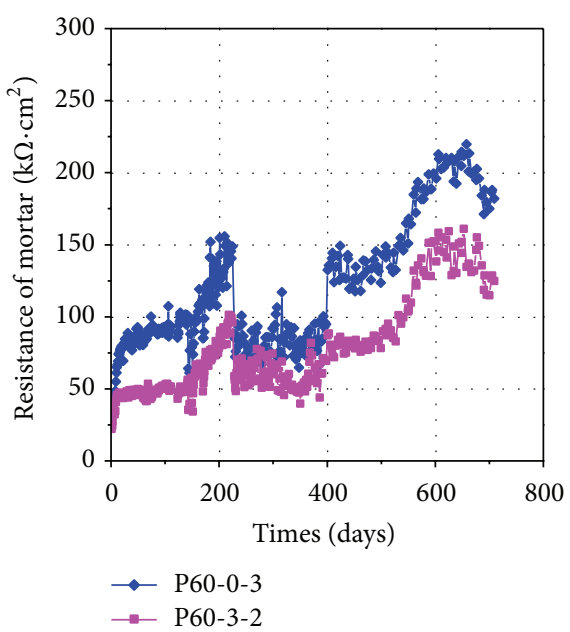

(f)

FIGURE 4: Time evolution curves of half-cell potential, microcell current density, macrocell current density, and resistance of mortars for cases with W/C ratio of 0.60 . (a) Half-cell potential of steel in case 10-1, (b) half-cell potential of steel in case 10-2, (c) corrosion current density of steel in case 10-1, (d) corrosion current density of steel in case 10-2, (e) resistance of mortar in case 10-1, and (f) resistance of mortar in case 10-2. 


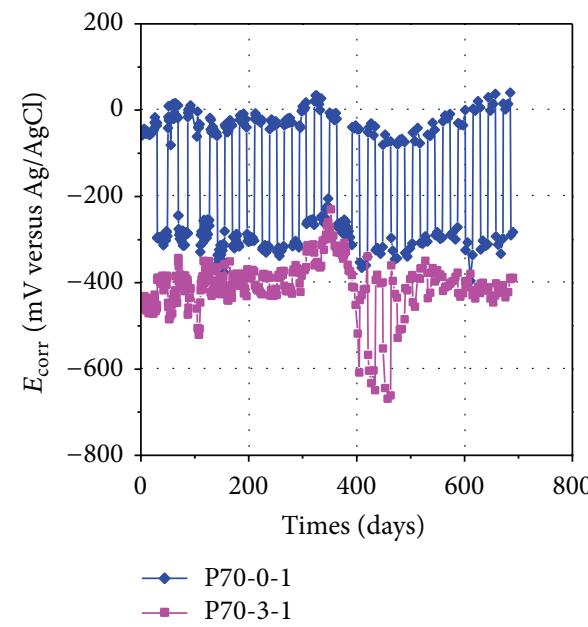

(a)

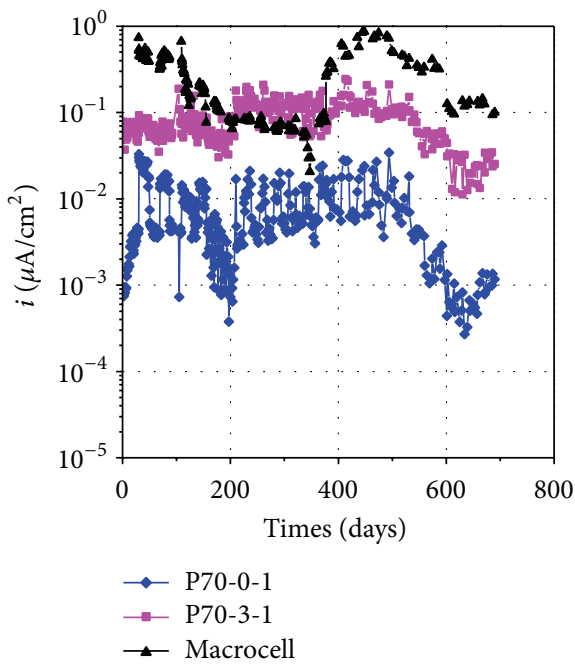

(c)

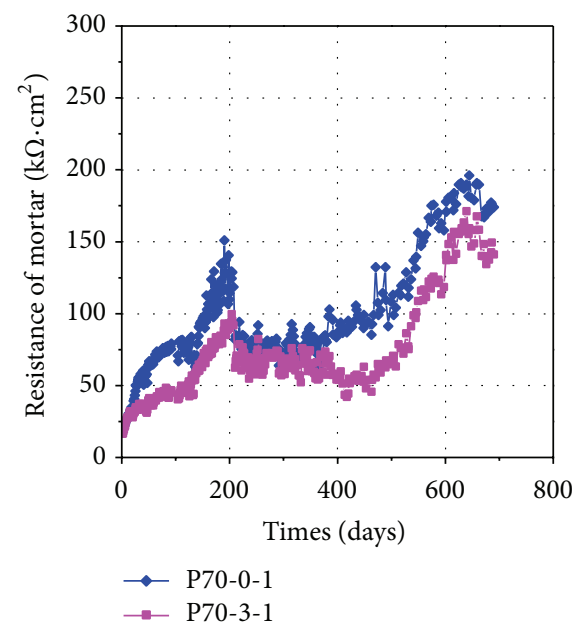

(e)

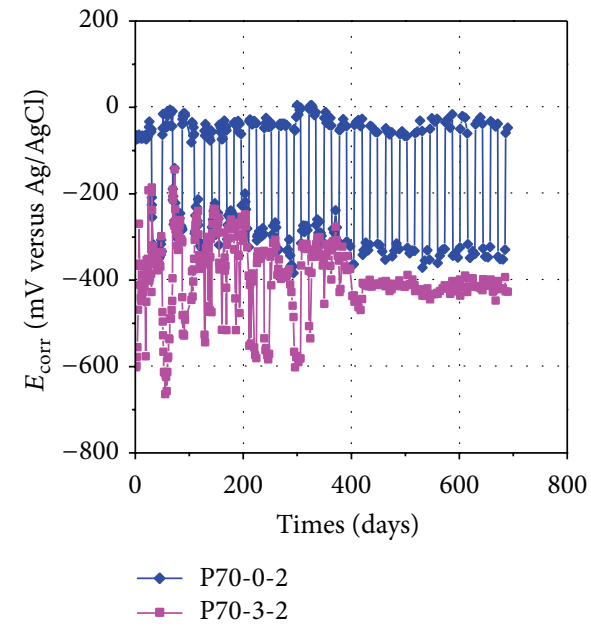

(b)

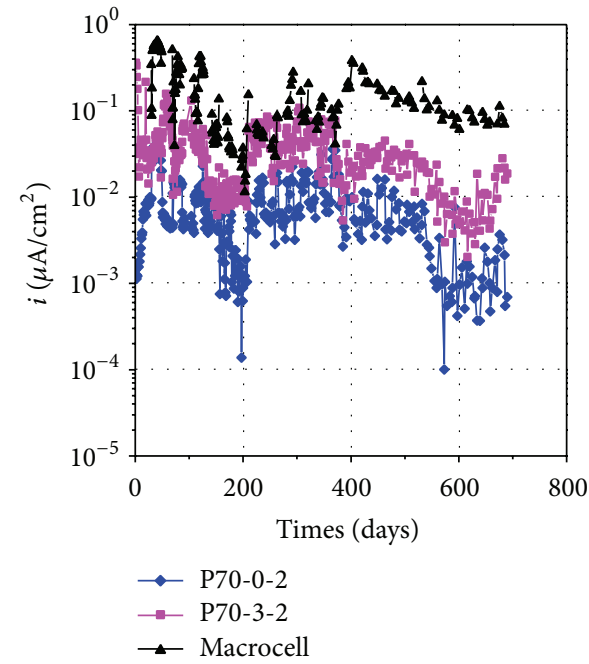

(d)

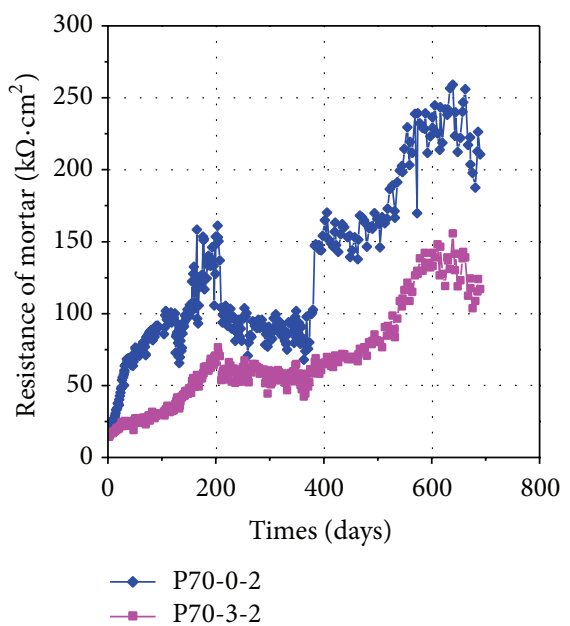

(f)

FIGURE 5: Time evolution curves of half-cell potential, microcell current density, macrocell current density, and resistance of mortars for cases with W/C ratio of 0.70. (a) Half-cell potential of steel in case 11-1, (b) half-cell potential of steel in case 11-2, (c) corrosion current density of steel in case 11-1, (d) corrosion current density of steel in case 11-2, (e) resistance of mortar in case 11-1, and (f) resistance of mortar in case 11-2. 
the microcell current density and macrocell current density of steels demonstrated a trend of decreasing in value. The resistance of mortars had an increasing trend due to the further hydration of cement. The variation of half-cell potential, microcell current density, and macrocell current density with time might be the result of the comprehensive effect of various factors such as temperature, moisture content, the resistance of mortar, the diffusion of oxygen, the change of microstructure of the interfacial transition zone [13], and the change of composition of corrosion products $[14,15]$.

\subsection{Effect of Water-Cement Ratios on the Relationships bet-} ween $\Delta E_{\text {corr }}$ and Macrocell Current Density. The potential difference between anodic and cathodic was one of the important factors to affect the macrocell current. In order to better understand the effect of water-cement ratios on the macrocell current, the relationship between potential difference and the macrocell current density was investigated. The definition of potential difference was given in Figure 6 . The $\Delta E_{\text {corr }} 1$ was defined as the potential difference between steel in $\mathrm{A}$-side and steel in B-side during the disconnected periods, and $\Delta E_{\text {corr }} 4$ was the potential difference between steel in A-side and steel $\mathrm{B}$-side during the connected periods. While $\Delta E_{\text {corr }} 2$ was the potential difference of steel in A-side during the disconnected periods and connected periods, $\Delta E_{\text {corr }} 3$ was the potential difference of steel in B-side during the disconnected periods and connected periods. The influence of water-cement ratios on the relationships between $\Delta E_{\text {corr }} i(i=1,2,3)$ and the macrocell current density was presented in Figure 7.

It could be seen from Figure 7(a) that the macrocell current density was a function of $\Delta E_{\text {corr }} 1$ and increased with the increasing of $\Delta E_{\text {corr }} 1$. The trend relationship between the macrocell current density and $\Delta E_{\text {corr }} 1$ was similar to the anodic polarization curve of anodic steel. The influence of water-cement ratios on the relationships between the macrocell current density and $\Delta E_{\text {corr }} 1$ could be observed from the experimental results. For the given $\Delta E_{\text {corr }} 1$, the macrocell current density that formed with different watercement ratios varied in a very wide range and parts of them overlapped each other. Seen from the overlapping regions in $\Delta E_{\text {corr }} 1$ that ranged $350 \sim 450 \mathrm{mV}$, the macrocell current densities that formed with water-cement ratios of 0.7 were relatively higher than those which formed in the cases with water-cement ratios of 0.6. Although these data overlapped each other in some extent, they were still discernible and therefore provided a support on the conclusion that the lower water-cement ratio played a role in reducing the macrocell current compared to the higher water-cement ratio in the condition of the same macrocell potential difference. Another finding was that the ranges of macrocell potential difference $\left(\Delta E_{\text {corr }} 1\right)$ decreased with the reduction of water-cement ratios. So another mechanism of lower water-cement ratios to inhibit the macrocell current was that the lower water-cement ratios could decrease the macrocell potential difference $\left(\Delta E_{\text {corr }} 1\right)$ and resulted in the decreasing of macrocell current.

Figure 7(b) shows the influence of water-cement ratios on the relationship between macrocell current density and $\Delta E_{\text {corr }} 2$ which represented the macrocell polarization degree

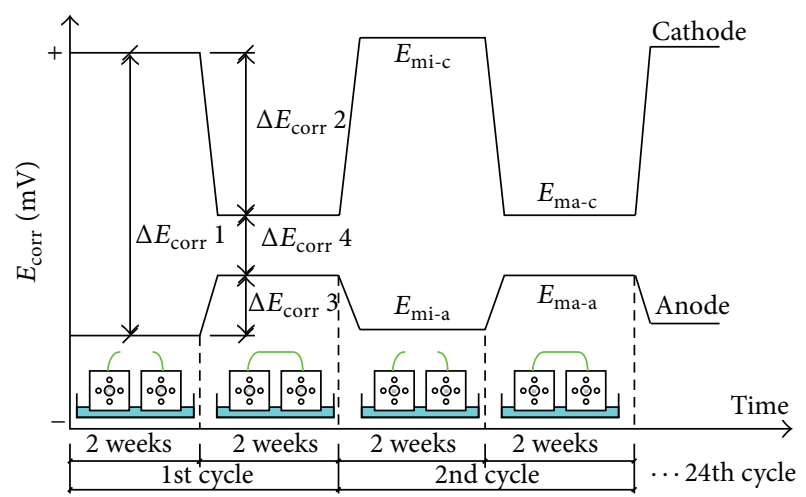

$$
\begin{aligned}
& \Delta E_{\text {corr }} 1=\left|E_{\text {mi-a }}-E_{\text {mi-c }}\right| \quad \Delta E_{\text {corr }} 3=\left|E_{\text {mi-a }}-E_{\text {ma-a }}\right| \\
& \Delta E_{\text {corr }} 2=\left|E_{\text {mi-c }}-E_{\text {ma-c }}\right| \\
& \text { Polarization ratio of steel in cathode }=\Delta E_{\text {corr }} 4=\left|E_{\text {ma-c }}-E_{\text {ma-a }}\right| \\
& 2 / \Delta E_{\text {corr }} 1 \\
& \text { Polarization ratio of steel in anode }=\Delta E_{\text {corr }} 3 / \Delta E_{\text {corr }} 1
\end{aligned}
$$

FIGURE 6: Definition of potential difference of macrocell corrosion.

of cathode. It was found that the macrocell current density rose with the increase of $\Delta E_{\text {corr }} 2$. For the given $\Delta E_{\text {corr }} 2$, the macrocell current density consumed by the cathodic steels embedded in mortars with different water-cement ratios varied in a wide range, once again, with portions of the ranges overlapping. Seen from the overlapping regions of $\Delta E_{\text {corr }} 2$ that ranged from $240 \sim 320 \mathrm{mV}$, the macrocell current densities consumed by the cathodic steels embedded in mortars with water-cement ratios of 0.6 were relatively lower than those in mortars with water-cement ratios of 0.7 and higher than those in mortars with water-cement ratio of 0.45 . The lower macrocell current density consumed by steel embedded in mortars with lower water-cement ratio indicated that lower water-cement ratio had an ability to inhibit the cathodic reaction and therefore could inhibit macrocell corrosion. Another finding was that the ranges of macrocell potential difference $\left(\Delta E_{\text {corr }} 2\right)$ of the cathode decreased with the reduction of water-cement ratios. An additional mechanism of the inhibition of macrocell current due to lower watercement ratios was that the lower water-cement ratios could decrease the macrocell potential difference $\left(\Delta E_{\text {corr }} 2\right)$ of cathode and resulted in the reduction of macrocell current.

Figure 7(c) describes the influence of water-cement ratios on the relationship between macrocell current density and $\Delta E_{\text {corr }} 3$ which represents the macrocell polarization degree of anode. It was also found that the macrocell current density produced by anodic steel was a function of $\Delta E_{\text {corr }} 3$ and rose with the increase of $\Delta E_{\text {corr }} 3$. A small macrocell potential difference of anodic steel could lead to the significant increase of macrocell current, which was similar to the anodic polarization behavior of anodic steel in the disconnected periods. When $\Delta E_{\text {corr }} 3$ ranged $1 \sim 100 \mathrm{mV}$, the magnitudes of macrocell current density decreased with the reduction of water-cement ratio. So the lower water-cement ratios could decrease the kinetics of anodic reactions and thus led to the decrease of macrocell current. For the same $\Delta E_{\text {corr }} 3$, the macrocell 


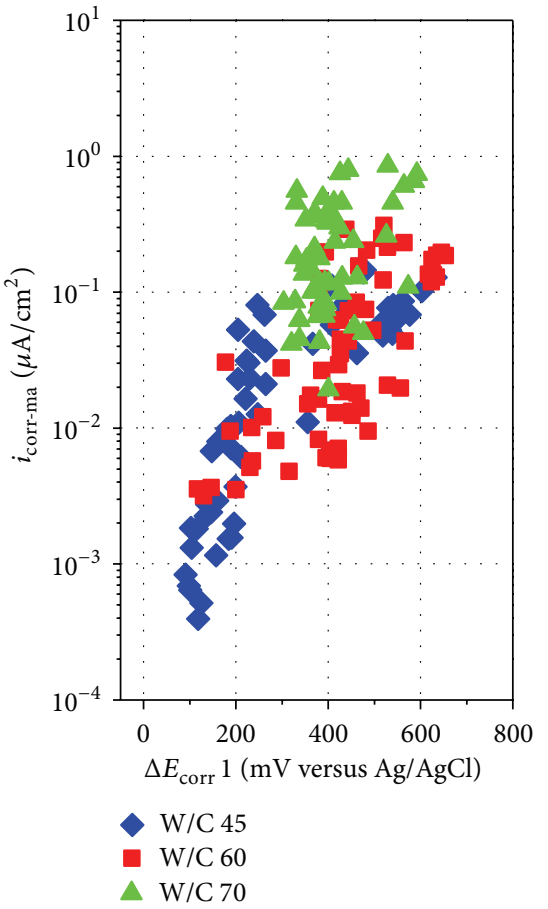

(a)

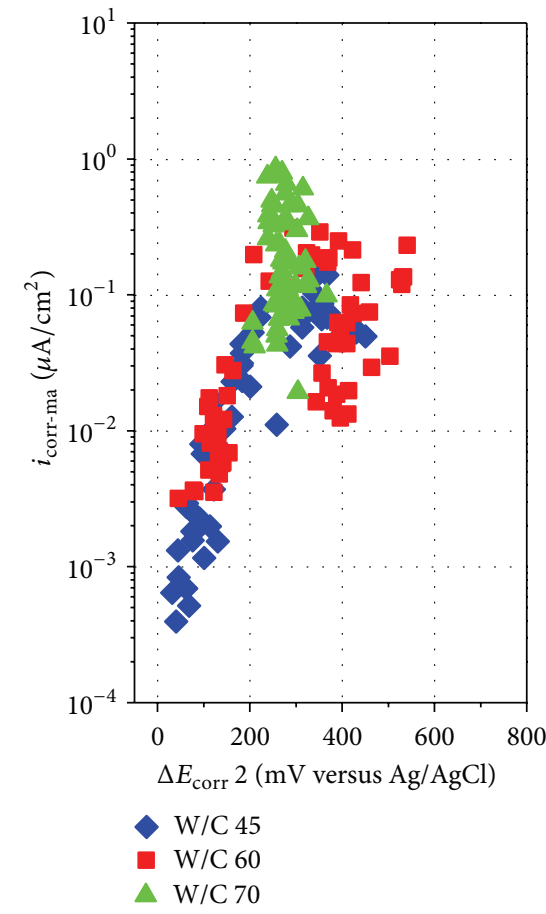

(b)

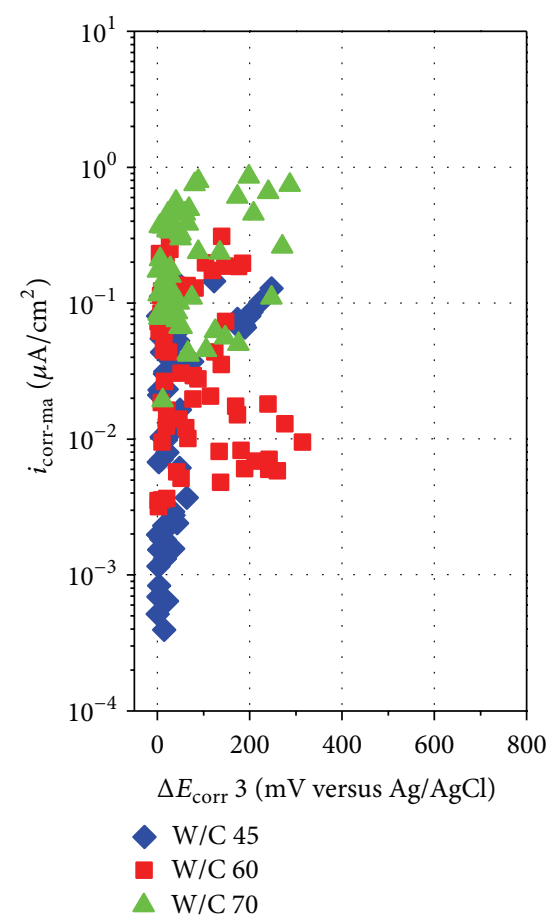

(c)

FIGURE 7: Effect of water-cement ratio on the (a) relationships between $\Delta E_{\text {corr }} 1$ and macrocell current density, (b) relationships between $\Delta E_{\text {corr }} 2$ and macrocell current density, and (c) relationships between $\Delta E_{\text {corr }} 3$ and macrocell current density.

current density distributed in a very wide range changed from the magnitude of $10^{-3} \mu \mathrm{A} / \mathrm{cm}^{2}$ to the magnitude of $10^{-1} \mu \mathrm{A} / \mathrm{cm}^{2}$. The large scatter of measured macrocell current density for the given macrocell potential difference indicated that the macrocell anodic potential difference $\left(\Delta E_{\text {corr }} 3\right)$ was not the only factor influencing the macrocell current; other factors such as temperature, moisture content of mortar, the supply of oxygen, and the kinetics of anodic and cathodic reactions might also have an influence on the magnitude of macrocell current.

\subsection{Effect of Water-Cement Ratios on the Macrocell Polariza-} tion Ratios of Cathode and Anode. In the macrocell corrosion state, it was important to know the relative contributions from the polarization of the cathode, anode, and the mortar resistance, as described by $\Delta E_{\text {corr }} 1=\Delta E_{\text {corr }} 2+\Delta E_{\text {corr }} 3+$ $\Delta E_{\text {corr }} 4$, which had been graphically illustrated previously. In order to obtain the relative contributions of $\Delta E_{\text {corr }} i$ ( $i=$ $2,3,4)$ on $\Delta E_{\text {corr }} 1$ for the cases with various water-cement ratios, the relationships between $\Delta E_{\text {corr }} 1$ and $\Delta E_{\text {corr }} i(i=$ $2,3,4)$ were plotted in Figure 8 and were fitted by the linear function. The slopes of the lines were defined as the macrocell polarization ratio of steel that acted as the cathode in Aside, the macrocell polarization ratio of steel that acted as the anode in B-side, and the macrocell polarization ratio of mortar resistance, respectively.

The influence of water-cement ratios on the macrocell polarization ratios of cathode, anode, and mortar resistance was summarized in Figure 9. It was found that the watercement ratios had little influence on the macrocell polarization ratios of cathode and anode. The macrocell polarization ratios of cathode were three times higher than that of anode, which indicated that the macrocell corrosion in this study was mainly controlled by the cathodic reaction of cathode.

\subsection{Effect of Water-Cement Ratios on the Macrocell Polariza-} tion Slopes of Cathode and Anode. The macrocell polarization slope of the cathode (anode) had been defined in the macrocell corrosion model proposed by Maruya et al. [9] as shown in Figure 10. The macrocell polarization slope of cathode was marked as $\beta_{\text {ma-c }}$, while the macrocell polarization slope of anode was marked as $\beta_{\text {ma-a }}$. The $\beta_{\text {ma-c }}$ or $\beta_{\text {ma-a }}$ can be calculated by the two points that represented the corrosion state of the cathodic or anodic steel in microcell corrosion state $\left(\left(i_{\text {mi-c }}, E_{\text {mi-c }}\right)\right.$ or $\left.\left(i_{\text {mi-a }}, E_{\text {mi-a }}\right)\right)$ and macrocell corrosion state $\left(\left(i_{\mathrm{ma}}, E_{\mathrm{ma}-\mathrm{c}}\right)\right.$ or $\left.\left(i_{\mathrm{ma}}, E_{\mathrm{ma}-\mathrm{a}}\right)\right)$. The value of the point that represented the corrosion state of cathodic (anodic) steel in microcell corrosion state was obtained by averaging the halfcell potential and the microcell current density obtained in the disconnected periods, while the value of the point that represented the corrosion state of cathodic (anodic) steel in macrocell corrosion state was obtained by averaging the halfcell potential and the macrocell current density obtained in the connected periods.

The macrocell polarization slopes of cathode $\left(\beta_{\mathrm{ma-c}}\right)$ and anode $\left(\beta_{\text {ma-a }}\right)$ reflect the polarization ability of cathode 


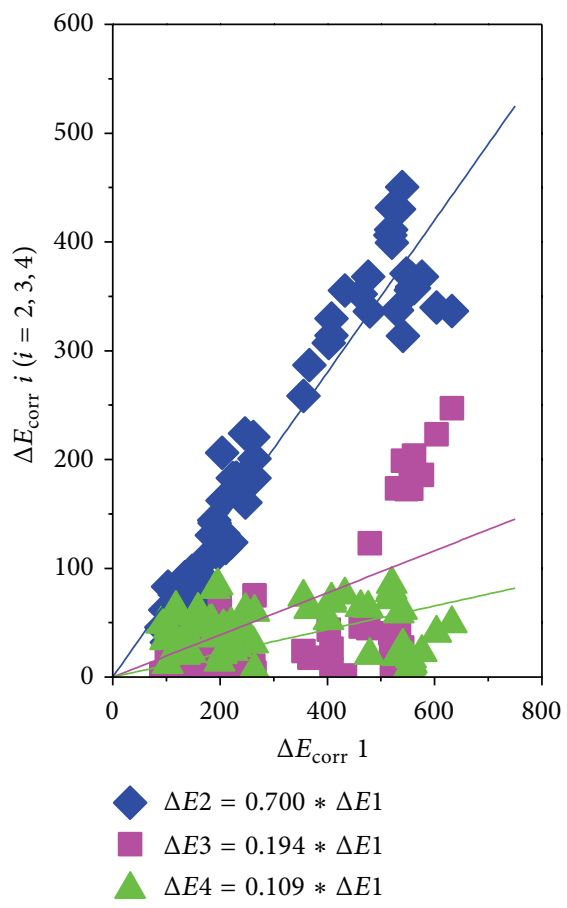

(a)

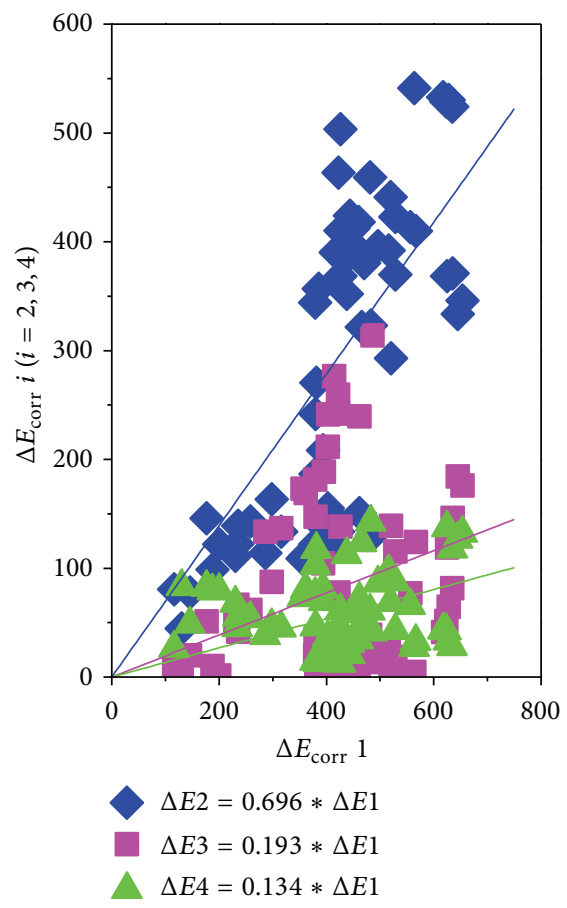

(b)

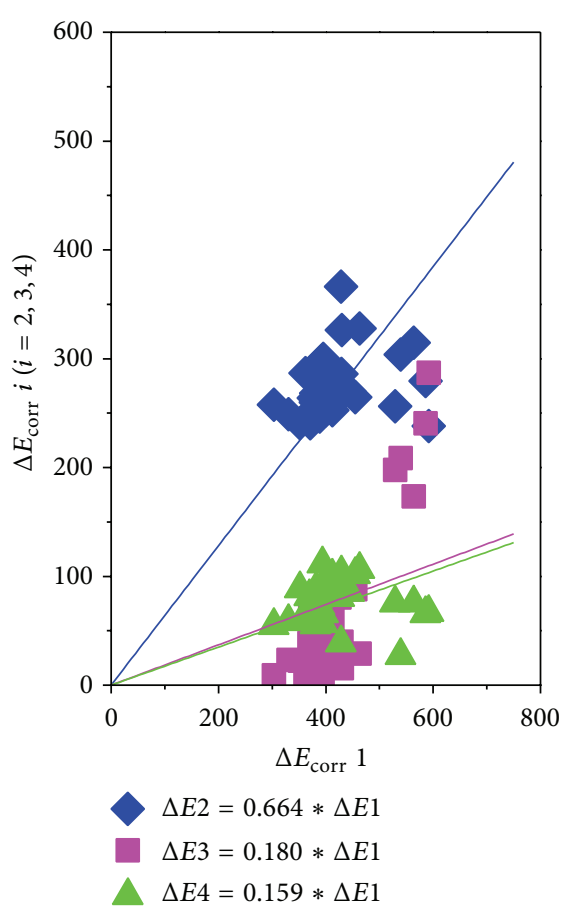

(c)

Figure 8: Relationships between $\Delta E_{\text {corr }} 1$ and $\Delta E_{\text {corr }} i(i=2,3,4)$. (a) Water-cement ratio $=0.45$, (b) water-cement ratio $=0.6$, and (c) water-cement ratio $=0.7$

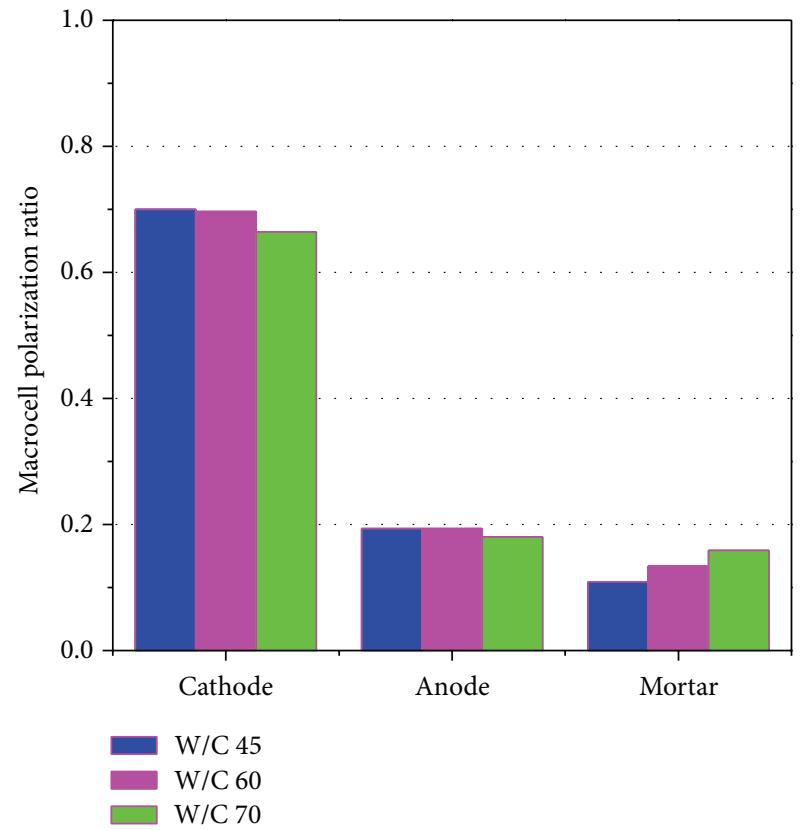

FIGURE 9: Effect of water-cement ratios on the macrocell polarization ratios of cathode and anode.

and anode in the macrocell corrosion state. The higher the $\beta_{\text {ma-c }}$, the stronger the ability of the cathode to receive the electrons, which means the lower macrocell polarization resistance of the cathode. The lower the $\beta_{\text {ma-a }}$, the stronger

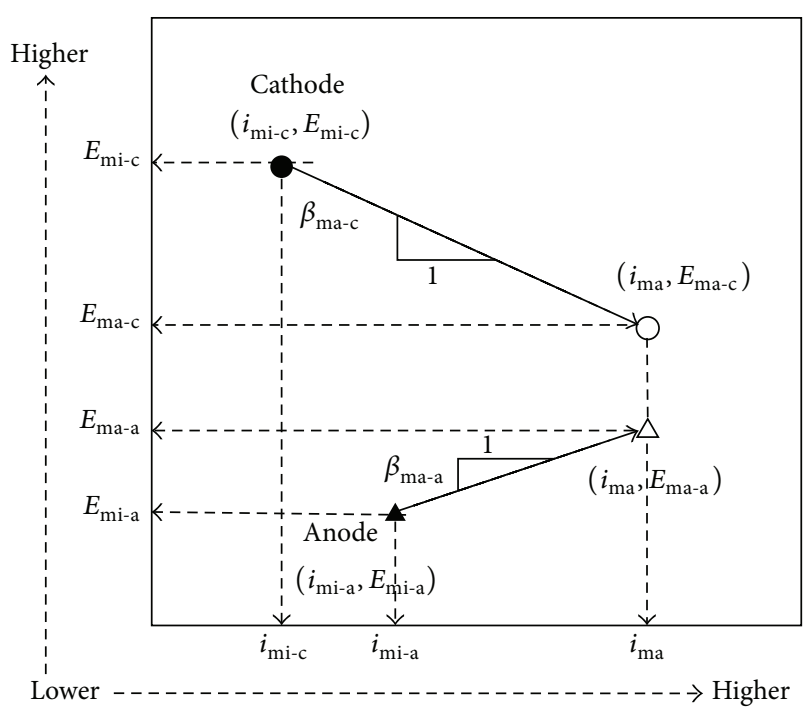

FIGURE 10: Definition of macrocell polarization slope of cathode and anode [9].

the ability of anode to produce the electrons, which results in a lower macrocell polarization resistance of the anode.

For the cases with various water/cement ratios, the average values and the standard deviation of macrocell slopes of cathode and anode ( $\beta_{\text {ma-c }}$ and $\beta_{\text {ma-a }}$ ) were analyzed statistically based on the data obtained from the 1st cycle to the 24th cycle. The results were presented in Figure 11. Seen from these results, it could be confirmed that the lower water/cement 


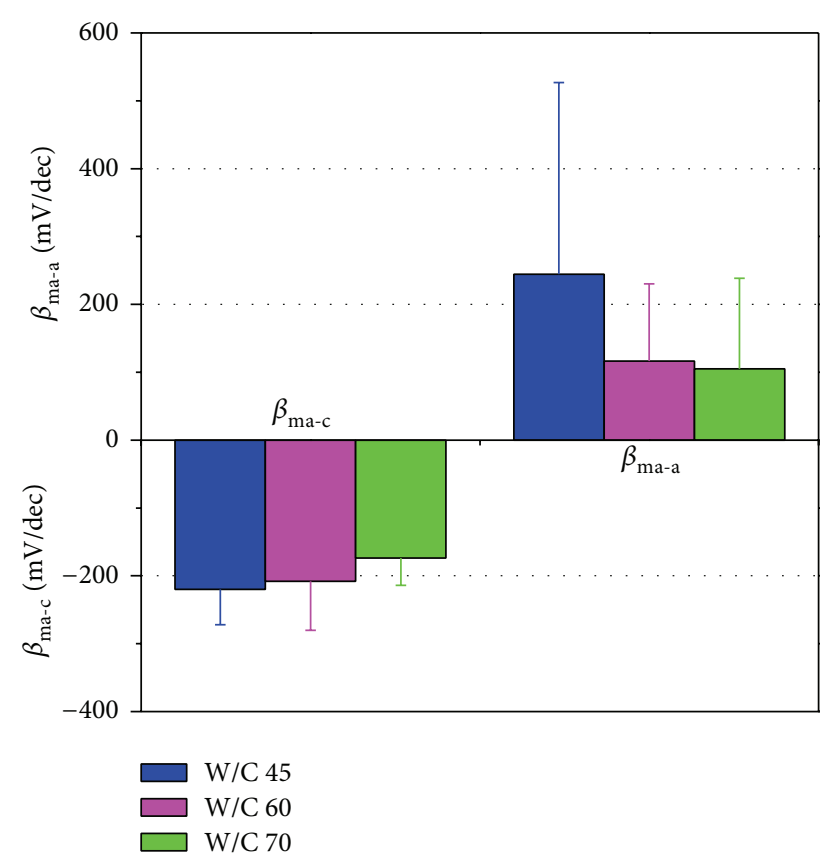

FIGURE 11: Effect of water/cement ratios on the macrocell polarization slopes of cathode and anode.

ratio could decrease the macrocell slope of cathode $\left(\beta_{\text {ma-c }}\right)$ and increase the macrocell slope of anode $\left(\beta_{\text {ma-a }}\right)$. This means that, in the macrocell corrosion state, the lower water-cement ratio could not only increase the macrocell polarization resistance of the cathode but also increase the macrocell polarization resistance of the anode.

3.5. Mechanism for Water-Cement Ratios to Affect the Macrocell Corrosion. Based on the above analysis, the mechanism for the lower water-cement ratio to reduce the macrocell current density was graphically illustrated in Figure 12 . Because the potential difference $\left(\Delta E_{\text {corr }} 1\right)$ between anode and cathode had a significant impact on the macrocell current density, the mechanism presented here was primarily based on the condition that the potential differences $\left(\Delta E_{\text {corr }} 1\right)$ were the same for all analyzed cases. The black lines and black points represented the macrocell polarization curves of the cathode and anode in mortar containing a high water-cement ratio. The macrocell slopes of the cathode and anode were marked as $\beta_{\text {ma-c-H }}$ and $\beta_{\text {ma-a-H }}$, respectively, and the macrocell current density was marked as $i_{\text {ma-H}}$. The decrease of water-cement ratio resulted in a weakening in the kinetics of cathodic and anodic reactions. The macrocell slope of cathode decreased from $\beta_{\text {ma-c-H }}$ to $\beta_{\text {ma-c-L }}$ while the macrocell slope of anode increased from $\beta_{\text {ma-a-H }}$ to $\beta_{\text {ma-a- } \mathrm{L}}$; this resulted in the decrease of macrocell current density from $i_{\text {ma-H }}$ to $i_{\text {ma-L }}$.

\section{Conclusions}

In this study, the macrocell polarization behaviors of cathodic and anodic steels had been confirmed. Due to the electrochemical driving force in terms of potential difference,

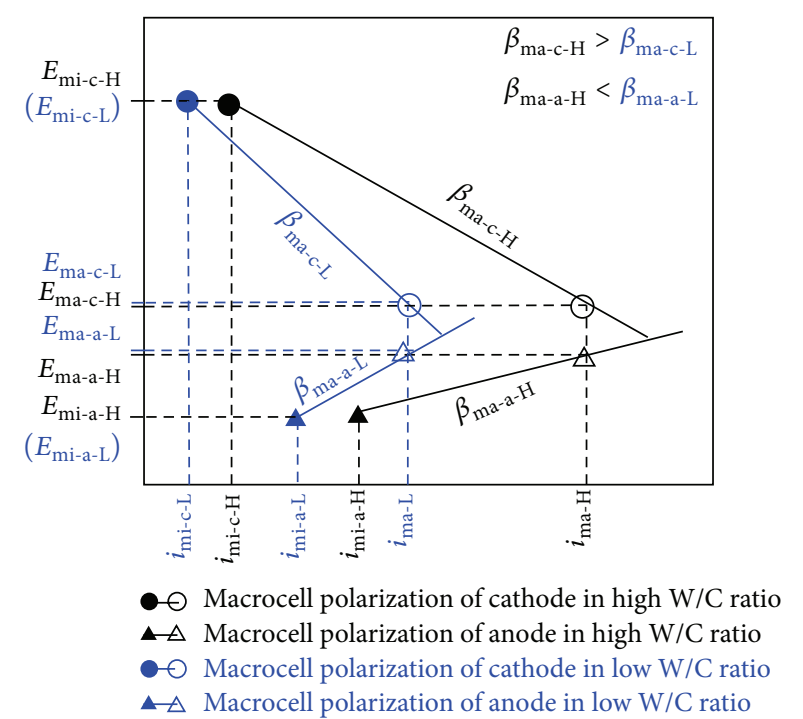

FIGURE 12: Mechanism of macrocell corrosion affected by watercement ratios.

the cathodic steel could be polarized to a lower potential and the anodic steel was polarized to a higher potential, which resulted in the formation of macrocell current.

The water-cement ratios had a significant influence on the magnitude of macrocell current. The lower water-cement ratio could effectively inhibit the macrocell current by weakening the kinetics of cathodic and anodic reactions and decreasing macrocell potential difference between cathode and anode.

The water-cement ratios had little effect on the macrocell polarization ratios of cathode and anode but impacted the macrocell polarization slopes of cathodic and anodic steels. The lower water-cement ratio could decrease the macrocell polarization slope of cathode and increase the macrocell polarization slope of anode. Thus, the lower water-cement ratio could not only increase the macrocell polarization resistance of cathode but also increase the macrocell polarization resistance of anode.

\section{Conflict of Interests}

The authors declare that there is no conflict of interests regarding the publication of this paper.

\section{References}

[1] C. Arya and P. R. W. Vassie, "Influence of cathode-to-anode area ratio and separation distance on galvanic corrosion currents of steel in concrete containing chlorides," Cement and Concrete Research, vol. 25, no. 5, pp. 989-998, 1995.

[2] R. Vedalakshmi, K. Rajagopal, and N. Palaniswamy, "Longterm corrosion performance of rebar embedded in blended cement concrete under macro cell corrosion condition," Construction and Building Materials, vol. 22, no. 3, pp. 186-199, 2008.

[3] C. M. Hansson, A. Poursaee, and A. Laurent, "Macrocell and microcell corrosion of steel in ordinary Portland cement and 
high performance concretes," Cement and Concrete Research, vol. 36, no. 11, pp. 2098-2102, 2006.

[4] Y. Ohno, K. Suzuki, and H. Tamura, "Effect of cover thickness and cracking on corrosion of steel in concrete," JCA Proceeding of Cement and Concrete, vol. 46, pp. 642-647, 1992 (Japanese).

[5] Y. Ohno, K. Suzuki, and H. Tamura, "Corrosion of steel in cracked concrete," in Proceedings of the JCA Proceeding of Cement and Concrete, vol. 47, pp. 504-509, 1993.

[6] Y. Ohno, K. Suzuki, and H. Tamura, "Corrosion of steel in cracked high strength concrete," JCA Proceedings of Cement \& Concrete, vol. 48, pp. 536-541, 1994 (Japanese).

[7] Y. Ohno, K. Suzuki, and H. Tamura, "Influence of various parameters on macrocell corrosion of steel in concrete," in Proceeding of the Cement and Concrete (JCA '95), vol. 46, pp. 726-731, 1995.

[8] M. Raupach, "Chloride-induced macrocell corrosion of steel in concrete-theoretical background and practical consequences," Construction and Building Materials, vol. 10, no. 5, pp. 329-338, 1996.

[9] T. Maruya, H. Takeda, K. Horiguchi, S. Koyama, and K.-L. Hsu, "Simulation of steel corrosion in concrete based on the model of macro-cell corrosion circuit," Journal of Advanced Concrete Technology, vol. 5, no. 3, pp. 343-362, 2007.

[10] A. Poursaee, A. Laurent, and C. M. Hansson, "Corrosion of steel bars in OPC mortar exposed to $\mathrm{NaCl}, \mathrm{MgCl}_{2}$ and $\mathrm{CaCl}_{2}$ : macroand micro-cell corrosion perspective," Cement and Concrete Research, vol. 40, no. 3, pp. 426-430, 2010.

[11] C. Andrade, I. R. Maribona, S. Feliu, J. A. González, and S. Feliu Jr., "The effect of macrocells between active and passive areas of steel reinforcements," Corrosion Science, vol. 33, no. 2, pp. 237249, 1992.

[12] Y.-S. Ji, W. Zhao, M. Zhou, H.-R. Ma, and P. Zeng, "Corrosion current distribution of macrocell and microcell of steel bar in concrete exposed to chloride environments," Construction and Building Materials, vol. 47, pp. 104-110, 2013.

[13] Y. Yuan, Y. Ji, and J. Jiang, "Effect of corrosion layer of steel bar in concrete on time-variant corrosion rate," Materials and Structures, vol. 42, no. 10, pp. 1443-1450, 2009.

[14] Y. Zou, J. Wang, and Y. Y. Zheng, "Electrochemical techniques for determining corrosion rate of rusted steel in seawater," Corrosion Science, vol. 53, no. 1, pp. 208-216, 2011.

[15] Z. L. Cao, M. Hibino, and H. Goda, "Effect of steel surface conditions on the macro-cell polarization behavior of reinforcing steel," Applied Mechanics and Materials, vol. 584-586, pp. 17711779, 2014. 

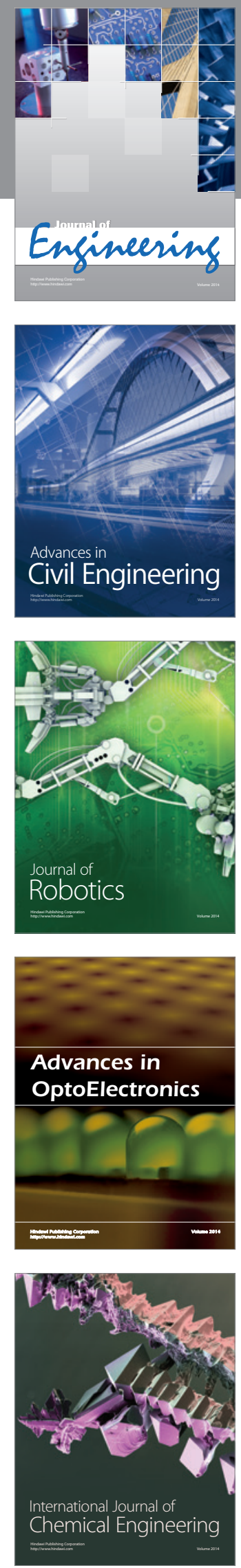

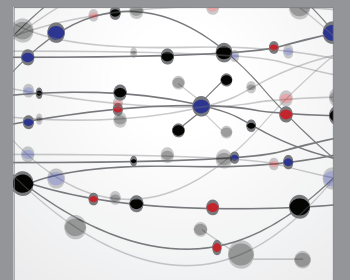

The Scientific World Journal
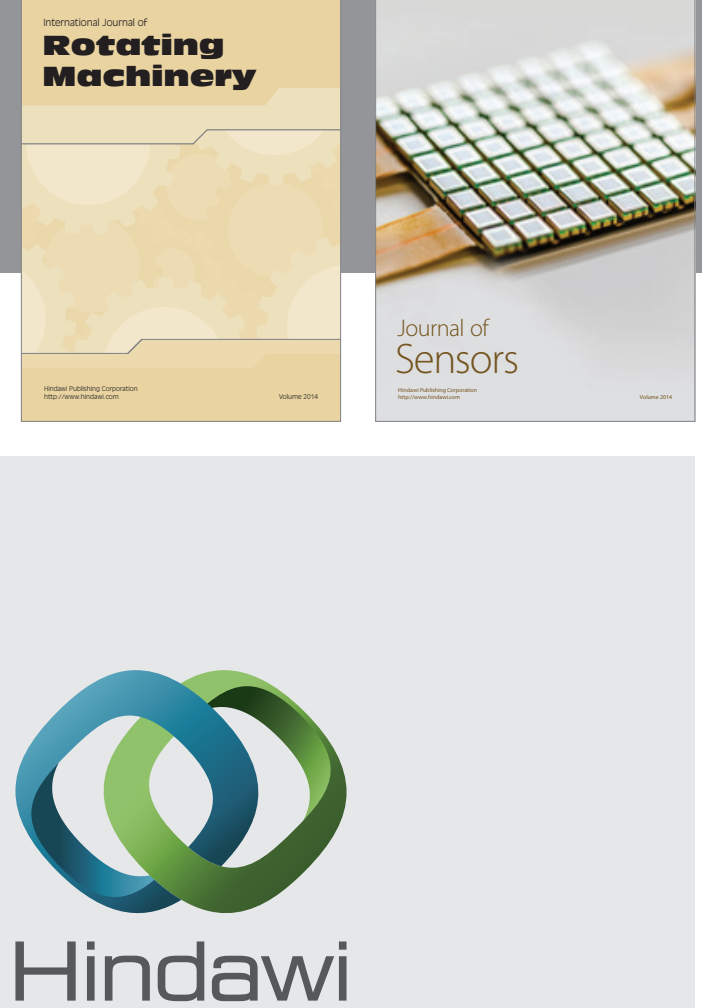

Submit your manuscripts at http://www.hindawi.com
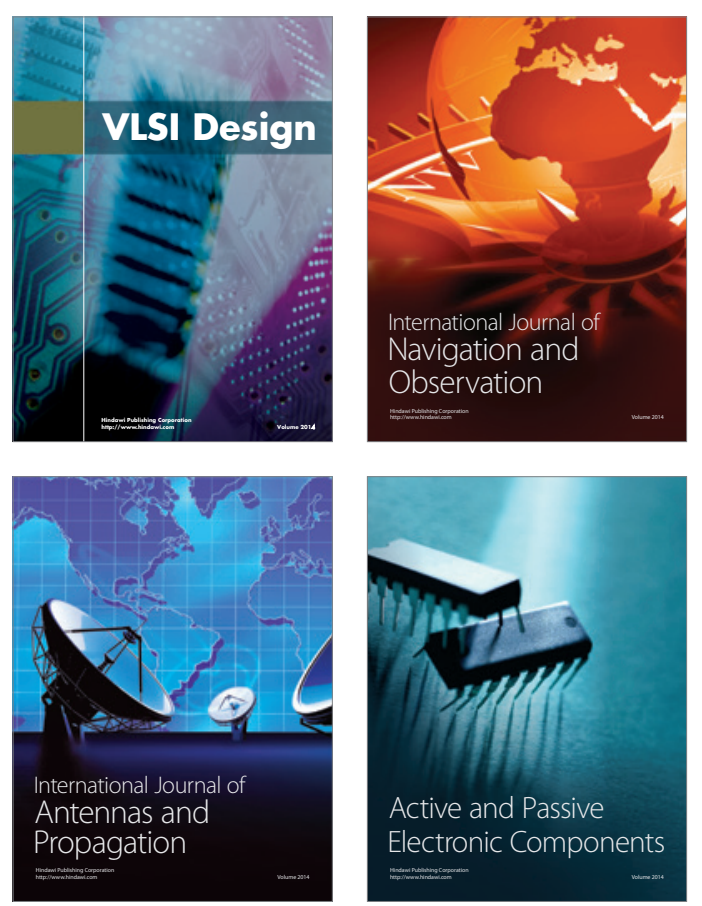
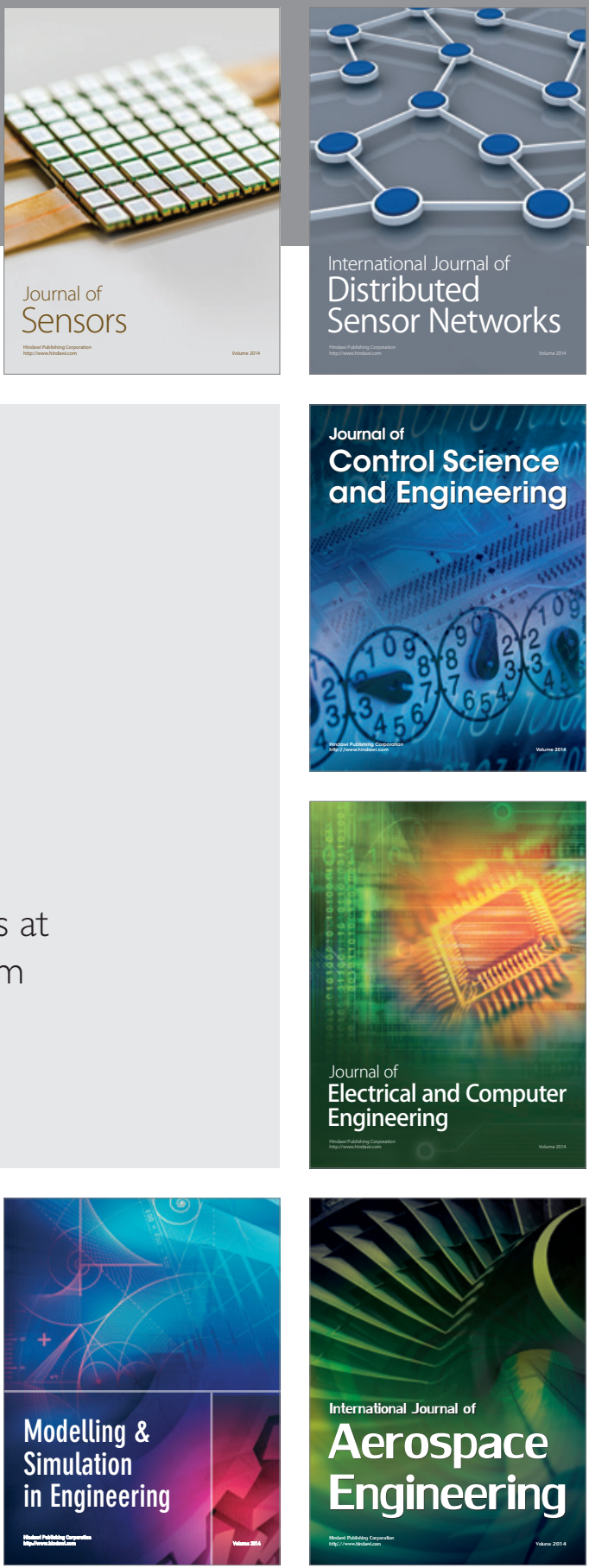

Journal of

Control Science

and Engineering
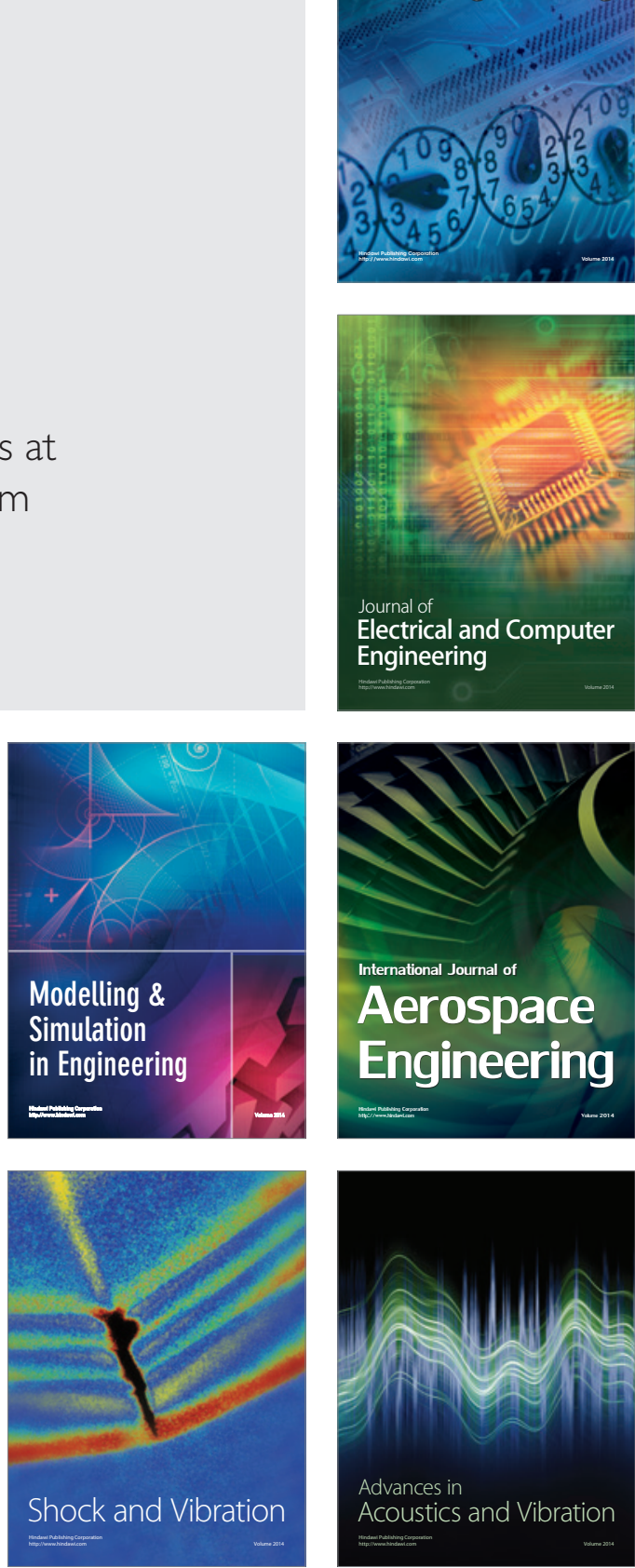